\title{
The use of Aloe Vera Gel Functionalized Biogenic Zinc-Oxide Nanoparticles Against Fish Putative Pathogens
}

\author{
Puja Pati ${ }^{1}$ (D), Kausik Mondal ${ }^{1}$ (D), Madhusudan Mandal ${ }^{2}$ (D)
}

Cite this article as: Pati, P., Mondal, K., \& Mandal, M. (2021). The use of Aloe vera gel functionalized biogenic Zinc-Oxide nanoparticles against fish putative pathogens. Aquatic Sciences and Engineering, 36(3), 101-108.

ORCID IDs of the author: P.P. 0000-0001-9366-2422; K.M. 0000-0003-2677-5966 M.M. 0000-0003-4277-4541

'Department of Zoology, University of Kalyani, Kalyani, Nadia, West Bengal, India ${ }^{2}$ Department of Chemistry, Mahadevananda Mahavidyalaya, Barrackpore, Kolkata, West Bengal, India

Submitted:

24.07.2020

Revision Requested: 19.09.2020

Last Revision Received: 03.10.2020

Accepted:

04.10 .2020

Online Published:

08.04.2021

Correspondence:

Puja Pati

E-mail:

pujapati.007@gmail.com

(c) Copyright 2021 The Author(s)

Available online at

https://dergipark.org.tr/ase

\begin{abstract}
Indiscriminate uses of antibiotics have resulted in the development of antibiotic-resistance among pathogens which possess a potential risk to the ecosystem, aquaculture and human health. In this study, biogenic zinc oxide nanoparticles ( $\mathrm{nnO}-\mathrm{NPs}$ ) were synthesized using aqueous extract of Aloe vera gel (AVGE) and tested against putative pathogenic bacterial strains in-vitro. Ultraviolet-Visible (UV-VIS) spectroscopic analysis confirmed the synthesis of AVGE-ZnO-NPs while X-ray diffraction (XRD) and Scanning Electron microscope (SEM) analysis revealed that the average size of synthesized $\mathrm{ZnO}-\mathrm{NPs}$ is within the nano range. The elemental and chemical compositions of synthesized ZnO-NPs were studied using Energy-dispersive X-ray spectroscopy (EDX) and Fourier-transform infrared (FTIR) spectrometer, respectively. Two widespread bacterial strains, Aeromonas veronii strain ONKP1 (MN602971) and Stenotrophomonas maltophilia strain ONKP2 (MN602972) that are known as emerging opportunistic pathogens in various marine and freshwater fishes as well as humans and other animals, were used as test organisms. AVGE-ZnO-NPs showed strong antibacterial activity, against the tested Gram-negative multi-drug resistant bacteria in the disc diffusion assay. The results of the present investigation could be useful for the development of new disease management strategies in the fisheries industry.
\end{abstract}

Keywords: Green nanoparticles, ZnO-NPs, Antibacterial, Aloe vera, Fish diseases

\section{INTRODUCTION}

The aquaculture industry highly depends on antibiotics such as erythromycin, tetracycline and streptomycin, to control bacterial infections in the farm. However unregulated and excessive use of antibiotics leads to the emergence of antibiotic resistance in fish pathogenic bacteria. Multi-drug resistant bacteria have been isolated from fish, sediment, and water of farms (Austin \& Austin, 2016; Shaalan et al., 2016). Since genetic elements can be shared between aquatic and terrestrial bacteria, human and animal pathogens can acquire such antibiotic-resistance genes from fish pathogens, arising public health issues (Swain et al., 2014; Luis et al., 2019). Thus, there is an urgent need to establish some novel strategies to combat antibiotic-resistance development and disease outbreaks in aquaculture without affecting the aquatic ecosystem. Recently, inorganic metal nanoparticles of silver, gold, titanium and zinc have generated widespread interest among aquaculture scientists as a potential alternative to antibiotics (Swain et al., 2014; Shaalan et al., 2016). They are considered as next-generation nanomedicine due to their unique pharmaceutical characteristics and novel pharmacological functions (De Villiers et al., 2008; Bharti \& Singh, 2009; Das et al., 2013).

Interestingly, Zinc oxide nanoparticles ( $\mathrm{ZnO}$ NPs) are emerging as a most promising metal based nanodrugs due to their biocompatibility, 
selectivity, and high potency (Bisht \& Rayamajhi, 2016; Elshama et al., 2018; Jin \& Jin, 2019). It is used in the area of drug delivery carrier, wound dressings, biosensors, bioimaging, medical devices, therapeutics, and diagnostics in medicine (Xiong, 2013; Zhu et al., 2016; Martínez-Carmona et al., 2018; Mirzaei \& Darroudi, 2017). ZnO-NPs are also valued as a source of the trace element zinc (Pati \& Mondal, 2019) which is required for the physiological development of animals, including fish (Watanabe et al., 1997). There are recent reports on the application of $\mathrm{ZnO}-\mathrm{NPs}$ in aquaculture as an alternative of conventional zinc sources as feed additive to promote growth (Faiz et al., 2015; Wang et al., 2017; Onuegbu et al., 2018) and immunity (Anjugam et al., 2018; Awad et al., 2019). Owing to their nano size and high specific surface area, $\mathrm{ZnO}-\mathrm{NPs}$ have several advantages over conventional $\mathrm{ZnO}$, such as higher bioavailability, molecular dispersion, and antibacterial properties (Swain et al., 2016; Raje et al., 2018). Currently, Ag-NPs are the most widely used inorganic antimicrobial nanomaterials in water disinfection, wastewater treatment (Dimapilis et al., 2018; Shah \& Mraz, 2020) and fish medicine (Shaalan et al., 2016; Khosravi-Katuli et al., 2017), but ZnO-NPs have the potential to be used as multifunctional material in aquaculture in coming years.

Green nanoparticles are mostly synthesized using plant parts like root, flower, leaves, fruit, stem, and seed extracts. Plant products are considered as safe, biocompatible, cheap, and environmentally friendly natural sources (Agarwal et al., 2017; Singh et al., 2018). ZnO-NPs have been successfully synthesized by using extracts of various plants, such as, Vitex trifolia (Elumalai et al., 2015), Catharanthus roseus (Gupta et al., 2018), Pongamia pinnata (Sundrarajan et al., 2015), Citrullus colocynthis (Azizi et al., 2017), Borassus flabellifer (Vimala et al., 2014) and Aloe vera (Sangeetha et al., 2011; Ali et al., 2016). Green $\mathrm{ZnO}$ nanoparticles are found to be a more potent antimicrobial agent than chemical $\mathrm{ZnO}$ nanoparticles on various human pathogenic strains like Staphylococcus aureus (Gunalan et al., 2012), Escherichia coli (Elumalai et al., 2015), Bacillus cereus (Gupta et al., 2018), Klebsiella pneumoniae (Mahendiran et al., 2017), Pseudomonas aeruginosa (Ali et al., 2016) and Bacillus subtilis (Chandran et al., 2018). However, studies on antibacterial activity of $\mathrm{ZnO}-\mathrm{NPs}$ as well as green NPs on aquatic pathogens are limited.

Aloe vera (synonym: Aloe barbadensis Miller) is a popular and easily available perennial succulent plant of the Liliaceae family. It is well known for its therapeutic properties like antimicrobial, antioxidant, anti-inflammatory, immunomodulatory, and wound healing from ancient times (Sangeetha et al., 2011). A. vera gel extract is reported to be rich in phytochemicals like terpenoids, phenols, alkaloids, carbohydrates, flavonoids, saponins, and tannins (Parthasarathy et al., 2017; Mahendiran et al., 2017). These phytochemicals help in nucleation and stabilization of nanoparticles during synthesis (Sangeetha et al., 2011; Ali et al., 2016). In the present study, $A$. vera gel extract has been used as a capping and stabilizing agent for the synthesis of $\mathrm{ZnO}-\mathrm{NPs}$. The antibacterial activity of synthesized biogenic $\mathrm{ZnO}-\mathrm{NPs}$ was evaluated against two Gram-negative fish pathogenic bacteria, Aeromonas veronii strain ONKP1 (MN602971) and Stenotrophomonas maltophilia strain ONKP2 (MN602972). A. veronii is a world-wide dis- tributed fish pathogen, causing hemorrhagic septicemia with high mortality rate (Sun et al., 2016; Tekedar et al., 2019). S. maltophilia is emerging as a pathogen in cultured catfishes in India (Abraham et al., 2016) and China (Geng et al., 2010). In China, it has become the most prevalent disease in cultured channel catfish, which spreads rapidly and causes mortality within a few days.

\section{MATERIALS AND METHODS}

\section{Synthesis of biogenic zinc oxide nanoparticles}

The biogenic ZnO-NPs were synthesized following the standard method of Patel et al., (2017) with slight modifications. Analytical grade zinc chloride $\left(\mathrm{ZnCl}_{2}, 99 \%\right.$ purity, Himedia, India) salt and sodium hydroxide pellets ( $\mathrm{NaOH}, 99 \%$ purity, Merck, India) were used as precursors. A total of $20 \mathrm{~g}$ gel was purified from the Aloe vera leaves that were collected from the university garden; boiled in double distilled water, and filtered to get the aqueous extract. Later, $50 \mathrm{~mL}$ aloe gel extract was added to $50 \mathrm{~mL} \mathrm{ZnCl}$ (quantity $=6.8167 \mathrm{~g}$ ) solution with constant stirring by a magnetic stirrer. Then the $\mathrm{pH}$ was adjusted to 12 by adding $2 \mathrm{M} \mathrm{NaOH}$ solution and stirred for another 30 minutes. The suspension was centrifuged and the supernatant was discarded. Then, the precipitate was washed twice with double distilled water and ethanol, respectively. The white product was collected on a watch glass and dried in a hot air oven at $80^{\circ} \mathrm{C}$ for 4 hours. The dried product was then crushed into powder and stored in a vacuum desiccator for future use. The possible chemical reactions were given below (Nath et al., 2018):

$$
\begin{aligned}
& \mathrm{ZnCl}_{2}+2 \mathrm{NaOH} \rightarrow \mathrm{Zn}(\mathrm{OH})_{2}+2 \mathrm{NaCl} \\
& \mathrm{Zn}(\mathrm{OH})_{2} \stackrel{80^{\circ}}{\rightarrow} \mathrm{ZnO}
\end{aligned}
$$

\section{Elemental analysis and chemical characterization of synthe- sized zinc oxide nanoparticles}

The synthesized ZnO-NPs have been characterized following the method of Mahendiran et al., (2017). Optical absorption spectrum for $\mathrm{ZnO}$-NPs was recorded in the UV-Vis (Ultraviolet-Visible) range using a UV-Vis spectrophotometer (UV-3092, Lablndia Analytical Instrument Pvt. Ltd.). The chemical composition of $\mathrm{ZnO}$ NPs was studied by using the Fourier-transform infrared (FTIR) spectrometer (Perkin Elmer L120-000A, spectral range 4000-450 $\mathrm{cm}^{-1}, \mathrm{KBr}$ pellets). The elemental composition of $\mathrm{ZnO}-\mathrm{NPs}$ was analyzed using the Energy-dispersive X-ray (EDX) spectroscopy (AMETEK EDAX). The morphology of the products was studied by using Scanning Electron microscope (SEM) (ZEISS Sigma 300). Phase purity and grain size were determined by $X$-ray diffraction (XRD) analysis (Brucker D8 Advance power-XRD, Cu-K $\alpha-\lambda=1.54$ $\AA$, range $2 \theta$ of $5-80^{\circ}$, scan speed $=0.2 \mathrm{~nm}$, step size $=0.2^{\circ}$ ).

\section{Determination of antibacterial activity and antibiotics sus- ceptibility \\ Microorganisms}

Two Gram-negative bacteria putative pathogenic strain, viz., Aeromonas veronii strain ONKP1 (MN602971), and Stenotrophomonas maltophilia strain ONKP2 (MN602972) are used in the present investigation. They were isolated from the gastrointestinal tract of fresh tilapia fish (Oreochromis niloticus) which were collected from local wet markets of Kalyani, Nadia, West Bengal. The bacteria 
were isolated and characterized (biochemical tests and 16S rRNA sequencing), as in previous studies (Ghosh et al., 2017).

\section{Disc diffusion assay}

The antibacterial activity of synthesized biogenic $\mathrm{ZnO}-\mathrm{NPs}$ and standard antibiotics was tested against the isolates, following the disc diffusion assay (Mahendiran et al., 2017). All discs and materials were autoclaved for sterilization before the experiments. Bacterial inocula were prepared by growing a single colony overnight in $5 \mathrm{ml}$ nutrient broth at $30^{\circ} \mathrm{C}$ and streaked onto Mueller-Hinton agar (Himedia, India) plates. Nanoparticle suspension of different concentrations viz. 5, 10, 20, 30, 40 and 50 $\mathrm{mg} / \mathrm{mL}$ were prepared in double distilled water and sonicated for the uniform suspension of nanoparticles. Then $10 \mu \mathrm{L}$ suspension was pipetted from each stock and impregnated onto respective $6 \mathrm{~mm}$ diameter sterile blank antibiogram discs. Then the dried discs containing different concentrations $(50,100,200$, 300,400 and $500 \mu \mathrm{g} /$ disc) were placed onto Mueller-Hinton agar. Discs of streptomycin $(100 \mu \mathrm{g})$, tetracycline $(30 \mu \mathrm{g})$ and ciprofloxacin $(5 \mu \mathrm{g})$ were prepared from their powder form (HiMedia, India) as described above. Commercial discs of erythromycin (15 $\mu \mathrm{g})$, ampicillin $(10 \mu \mathrm{g})$, penicillin-G $(10 \mu \mathrm{g})$, chloramphenicol (30 $\mu \mathrm{g})$ and amoxicillin $(30 \mu \mathrm{g})$ (Himedia, India) were also used. After incubation at $37^{\circ} \mathrm{C}$ for $24 \mathrm{~h}$, the diameter of the inhibition zones around discs were measured with a ruler. The disc diffusion assay was performed in triplicate for nanoparticle and antibiotics. The results were expressed as means \pm standard errors.

\section{RESULTS AND DISCUSSIONS}

\section{Elemental analysis and chemical characterization findings of zinc oxide nanoparticles UV-Vis analysis}

The sample exhibits strong UV-absorption spectra with maximum absorption at $340 \mathrm{~nm}$ (Fig. 1). Similar observations have been reported on the green synthesis of stable $\mathrm{ZnO}-\mathrm{NPs}$ (Varghese \& George, 2015; Qian et al., 2015). The optical absorbance spectra of noble metal nanoparticles are known to shift to longer wavelengths (red shift) with increasing particle size and to smaller wavelengths (blue shift) with decreasing particle size, due to Surface Plasmon Resonance (SPR). Moreover, only a single SPR band is found in the absorption spectra of spherical nanoparticles, whereas anisotropic and non-spherical shaped particles could give rise to two or more SPR bands depending on symmetry (Sangeetha et al., 2011). Hence, the results of UV absorption spectra of synthesized ZnO-NPs indicate its smaller particle size and spherical shape which is further validated.

\section{$\mathrm{XRD}$ analysis}

The XRD pattern of AVGE-ZnO-NPs (Fig. 2) shows Bragg reflections at $2 \theta$ values of $31.42^{\circ}(100), 34.01^{\circ}(002), 36.10^{\circ}(101)$, $47.26^{\circ}(102), 56.22^{\circ}(110), 62.50^{\circ}(103), 66.18^{\circ}(200), 67.38^{\circ}(112)$, $68.77^{\circ}(201), 72.26^{\circ}(004)$ and $76.84^{\circ}(202)$ that are in good agreement with JCPDS CARD NO: 36-1451. The plane values of XRD patterns confirm the hexagonal wurtzite structure of $\mathrm{ZnO}-\mathrm{NPs}$ (Sangeetha et al., 2011; Ali et al., 2016). The sample also shows diffraction peaks of the orthorhombic form of $\mathrm{Zn}(\mathrm{OH})_{2}$ (JCPDS CARD NO: 38-0385), which probably arose from surface hydroxylation of $\mathrm{ZnO}$ (Deb et al., 2013). The average particle size (D) of

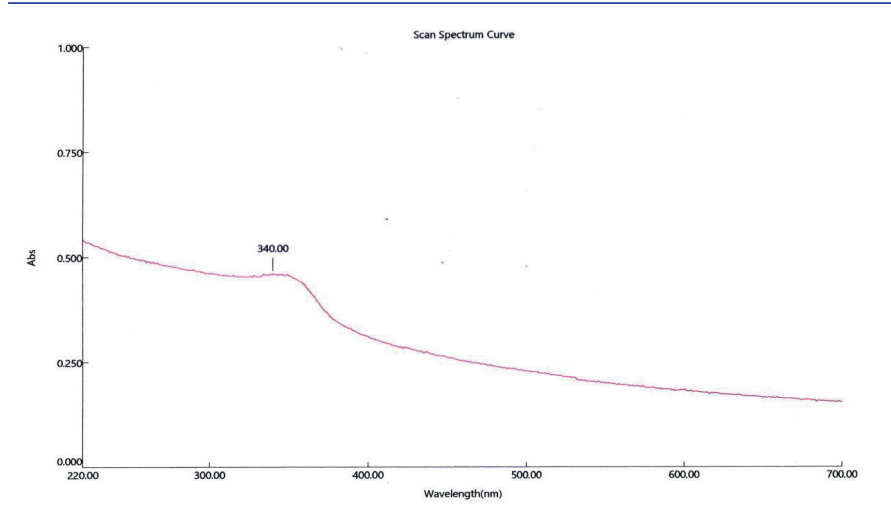

Figure 1. UV-Vis spectra of AVGE-ZnO-NPs.

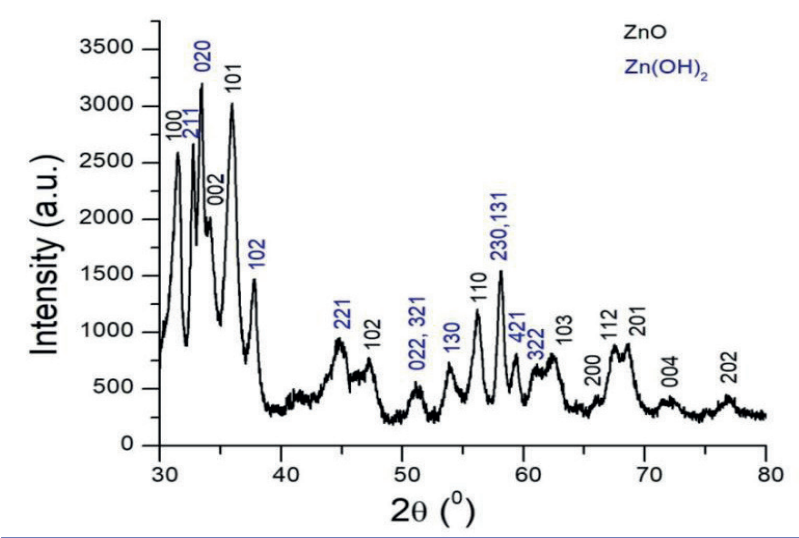

Figure 2. XRD Pattern of AVGE-ZnO-NPs.

synthesized nanoparticles is calculated using the Scherrer's formula, $\mathrm{D}=K \lambda /(\beta \cos \theta)$, where $\mathrm{D}$ is the crystal size, $K$ is a shape factor (it is a constant; approximately equal to 0.9 ), $\lambda$ is the $X$-ray wavelength, $\theta$ is the Bragg's angle in radians and $B$ the full line width at half maximum (FWHM) of the main intensity peak in radians (Mahendiran et al., 2017). The value of $D$ is obtained as 9.72 $\mathrm{nm}$ by taking 101 as the main intensity peak for calculation.

\section{SEM and EDX analysis}

The SEM images (Fig. 3) show the spherical and rod shaped AVGE-ZnO-NPs. The nanoparticles are found to be agglomerated with a particle size ranging from $37.5-63.75 \mathrm{~nm}$. The agglomeration could be induced by the densification and microstructural changes resulting in the narrow space between particles and also decreased pore size and diameter (Sangeetha et al., 2011). The SEM results of AVGE-ZnO-NPs are similar to previous studies on green ZnO-NPs (Vimala et al., 2014; Qian et al., 2015; Chandran et al., 2018).

The EDX analysis confirms the presence of metallic zinc ( $Z n$ ) (79.21\%) and oxygen (O) (20.79\%) as elements in AVGE-ZnO-NPs (Fig. 4). The EDX spectra of AVGE-ZnO-NPs exhibit three characteristic emission peaks of metallic $\mathrm{Zn}$ and one small emission peak from O element (Ali et al., 2016). Besides Zn and O, EDX spectra shows a weak signal of $\mathrm{Cl}$ element which is probably from precursor $\mathrm{ZnCl}_{2}$ or compounds present in aloe extract. 


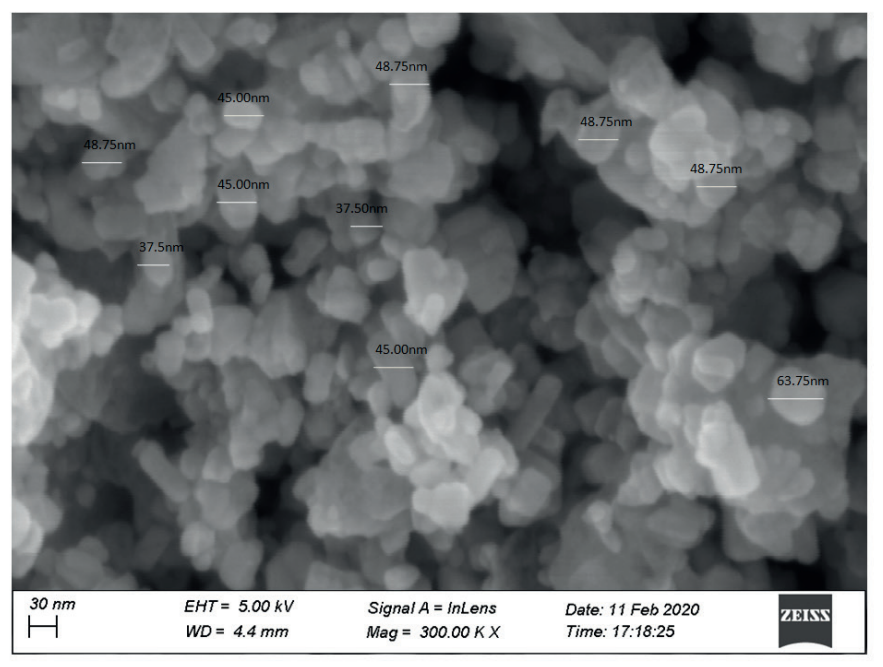

Figure 3. SEM of AVGE-ZnO-NPs $(37.3-63.75 \mathrm{~nm})$.

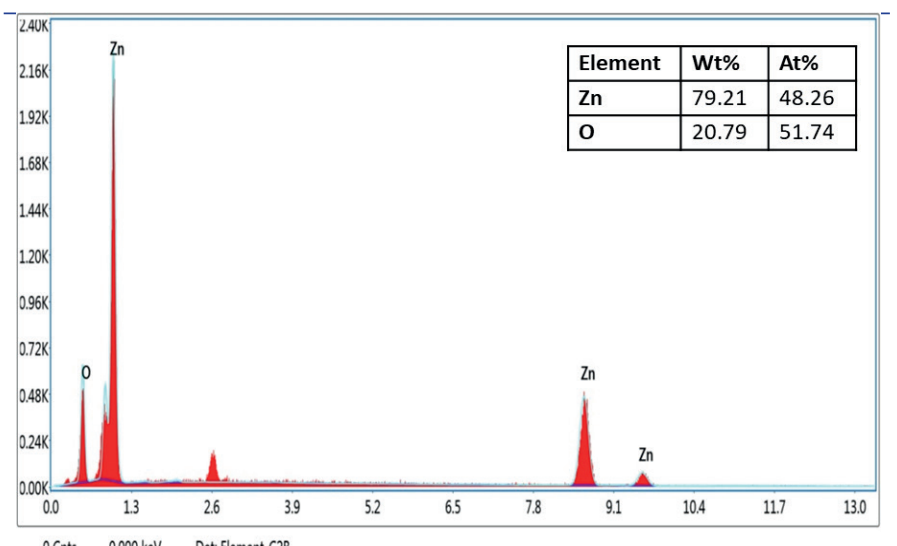

0 Cnts $\quad 0.000 \mathrm{keV} \quad$ Det: Element-C2B

Figure 4. EDX spectrum of AVGE-ZnO-NPs.

\section{FTIR analysis}

The infra-red (IR) spectrum of AVGE-ZnO-NPs shows characteristic absorption bands at $470.83 \mathrm{~cm}^{-1}$ and $535.57 \mathrm{~cm}^{-1}$ owing to the presence of two transverse optical stretching modes of $\mathrm{Zn}-\mathrm{O}$ (Elumalai et al., 2015; Patel et al., 2017) (Fig. 5). The peak in the region between 600 and $400 \mathrm{~cm}^{-1}$ is allotted to $\mathrm{Zn}-\mathrm{O}$ bond vibrational frequencies (Sangeetha et al., 2011). The absorption band observed at $626.99 \mathrm{~cm}^{-1}$ and $708.76 \mathrm{~cm}^{-1}$ indicates the deformation of Zn-O bond (Chandran et al., 2018) and C-N stretching of amine group, respectively (Gupta et al., 2018). The peaks at $897.17 \mathrm{~cm}^{-1}, 1620.40 \mathrm{~cm}^{-1}$ and $3460 \mathrm{~cm}^{-1}$ are due to $\mathrm{C}-\mathrm{H}$ bond of alkene group, amide I of proteins/enzymes and stretching vibration of $\mathrm{O}-\mathrm{H}$ groups in adsorbed moisture, alcohol and phenolic compounds (Mahendiran et al., 2017). $1037.14 \mathrm{~cm}^{-1}$ and 2927.15 $\mathrm{cm}^{-1}$ are assigned to stretching vibrations of $\mathrm{C}-\mathrm{H}$ and $\mathrm{C}-\mathrm{O}$ (Zhou et al., 2017). The peaks in the region of $2900-3700 \mathrm{~cm}^{-1}$ also correspond to amide linkages between amino acid residues of the proteins (Sangeetha et al., 2011). The intense band at $1476.92 \mathrm{~cm}^{-1}$ can be attributed to alcohols and phenolic groups, $\mathrm{C}-\mathrm{N}$ groups of aliphatic and aromatic amines and - $\mathrm{C}-\mathrm{O}-\mathrm{C}-$ or $-\mathrm{C}-\mathrm{O}-$ bonds of alkaloids and flavones (Patel et al., 2017). Thus, the results of
FTIR spectrum suggest the role of biological molecules (alkaloid, flavonoid, phenolic compounds, proteins etc.) present in the plant extract as a capping and stabilizing agent for the synthesis of $\mathrm{ZnO}-\mathrm{NPs}$.



Figure 5. FTIR spectra of AVGE-ZnO-NPs.

\section{Antibacterial activity and Antibiotics susceptibility findings}

In the in-vitro disc diffusion assay, the presence of clear inhibition zones around the discs indicates the bactericidal activity of AVGE-ZnO-NPs as well as antibiotics (Fig. 6). The antibacterial effect of AVGE-ZnO-NPs and other antibiotics were quantitatively assessed based on the diameter of the inhibition zones which was shown in Table 1. A graphical representation of the zone of inhibition of bacterial pathogens against different antimicrobials was illustrated in Fig 7a. Whereas, In Fig 7b, a graphical representation comparing the zone of inhibition between the highest dose of nanoparticles and the antibiotics to which the bacteria showed susceptibility, was given. The results indicate that the AVGE-ZnO-NPs have good inhibitory activity at all concentrations (50-500 $\mu \mathrm{g} / \mathrm{disc}$ ) against all the bacterial strains, in comparison to standard commercially available chemotherapeutic agents. In the present study, the inhibitory effect of AVGE-ZnONPs increased steadily with the increasing concentration. AVGE$\mathrm{ZnO}-\mathrm{NPs}$ showed a maximum zone of inhibition $(15.67 \pm 1.20 \mathrm{~mm})$ at the highest concentration of $500 \mu \mathrm{g} / \mathrm{disc}$ or $50 \mathrm{mg} / \mathrm{ml}$. As the concentration increases, the diffusion rate of $\mathrm{ZnO}-\mathrm{NPs}$ increase in the agar medium, causing increased antibacterial activity at higher concentrations (Gunalan et al., 2012).

Both A. veronii and S. maltophilia, are known to cause serious epidemic disease outbreaks in fish farms, with dominant clinical signs of skin ulcers (Nawaz et al., 2006; Austin \& Austin, 2012) and ascites (Geng et al., 2010), respectively. Several studies have isolated S. maltophilia from diseased fishes, for example, yellowtail (Furushita et al., 2005), giant gourami (Musa et al., 2008), channel catfish (Geng et al., 2010) and African catfish (Abraham et al., 2016). A. veronii is reported to be associated with infections in a number of economically important fish, including cichlid oscar (Sreedharan et al., 2011), gibel carp (Sun et al., 2016), tilapia (Hassan et al., 2017) and channel catfish (Hoai et al., 2019). They are also known as opportunistic pathogens in human and other animals (Gopalakrish- 

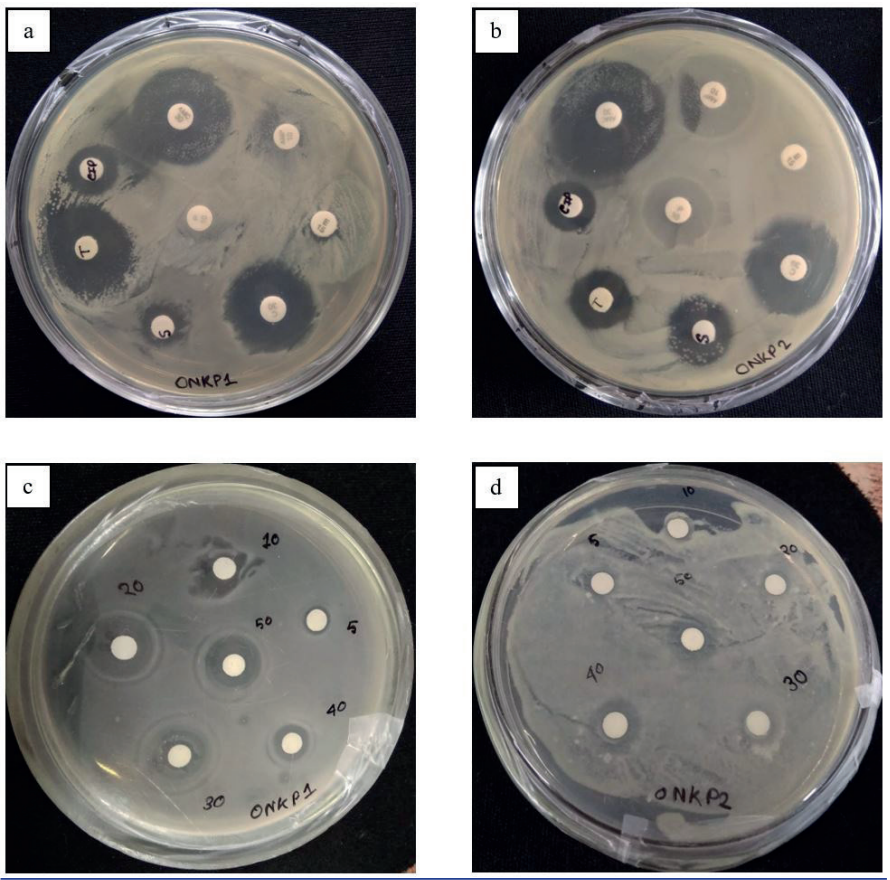

Figure 6. Antimicrobial activity of Standard antibiotics $(a, b)$ and AVGE-ZnO-NPs (c,d) against A. veronii ONKP1 $(a, c)$ and S. maltophilia ONKP2 (b,d). In $c$ and $d$, nanoparticle concentration was written as per stock value $(5-50 \mathrm{mg} / \mathrm{ml})$ which would be $50-500 \mu \mathrm{g} /$ disc. (E = Erythromycin; $\mathrm{C}=$ Chloramphenicol; $\mathrm{AMP}=$ Amoxicillin; $A M P=$ Ampicillin; $P=$ Penicillin-G; $T=$ Tetracycline; $\mathrm{CIP}=$ Ciprofloxacin; $\mathrm{S}=$ Streptomycin).

nan et al., 1999; Nawaz et al., 2006; Janda \& Abbott, 2010; Geng et al., 2010). Studies have found that a variety of commercially available antimicrobial agents like, $\beta$-lactams, quinolones, aminoglycosides and tetracycline are resisted by $A$. veronii (Sun et al., 2016; Nawaz et al., 2006) and S. maltophilia (Looney et al., 2009; Geng et al., 2010) which makes them very difficult to control. In the current study, A. veronii and S. maltophilia were also found to be resistant against erythromycin, ampicillin and penicillin-G, whereas susceptible to tetracycline, ciprofloxacin, streptomycin, chloramphenicol and amoxicillin. Moreover, Oreochromis spp. has been reported to carry antibiotic-resistant pathogenic bacteria such as, Salmonella (Budiati et al., 2013), Aeromonas hydrophila (Marathe et al., 2016), Klebsiella pneumoniae (Marathe et al., 2016; Thongkao \& Sudjaroen, 2019) and Staphylococci (Thongkao \& Sudjaroen, 2019) in their internal organs and is considered as a reservoir of zoonotic diseases. The results of our study also suggest that the marketed Nile tilapias ( $O$. niloticus) can carry antibiotic-resistant human pathogenic bacteria like $A$. veronii and $S$. maltophilia, which is a concern of microbiological safety.

Previously, Swain et al., (2014) has studied various metal nanoparticles including $\mathrm{Zn}, \mathrm{ZnO}, \mathrm{CuO}, \mathrm{Ag}, \mathrm{Al}_{2} \mathrm{O}_{3}, \mathrm{Ag}-\mathrm{TiO}_{2}$ and $\mathrm{Fe}_{2} \mathrm{O}_{3}$ (both commercial and laboratory synthesized) as potential antimicrobial agents against bacterial isolates such as A. hydrophila, Edwardsiella tarda, Pseudomonas aeruginosa, Flavobacterium branchiophilum, Vibrio sp., Staphylococcus aureus, Bacillus cereus and Citrobactersp. which were isolated from various diseased
Table 1. Antimicrobial activity of green synthesized $\mathrm{ZnO}$ nanoparticles (AVGE-ZnO-NPs) and standard antibiotics against putative fish pathogenic bacterial strains

\begin{tabular}{|c|c|c|}
\hline \multirow{2}{*}{$\begin{array}{l}\text { Samples ( } \mu \mathrm{g} / \\
\text { disk) }\end{array}$} & \multicolumn{2}{|c|}{$\begin{array}{c}\text { Bacterial Strain/Zone of inhibition } \\
(\text { Mean } \pm \text { SE } \mathrm{mm})^{\mathrm{b}}\end{array}$} \\
\hline & $\begin{array}{c}\text { Aeromonas } \\
\text { veronii } \\
\text { ONKP1 }\end{array}$ & $\begin{array}{c}\text { Stenotrophomonas } \\
\text { maltophilia } \\
\text { ONKP2 }\end{array}$ \\
\hline \multicolumn{3}{|l|}{ AVGE-ZnO-NPs } \\
\hline $50 \mu \mathrm{g}$ & $8.33 \pm 0.33$ & $7.67 \pm 0.33$ \\
\hline $100 \mu \mathrm{g}$ & $10.33 \pm 0.33$ & $8.67 \pm 0.67$ \\
\hline $200 \mu \mathrm{g}$ & $11.33 \pm 0.67$ & $12 \pm 1$ \\
\hline $300 \mu \mathrm{g}$ & $12.33 \pm 1.33$ & $14.67 \pm 0.33$ \\
\hline $400 \mu \mathrm{g}$ & $13 \pm 1$ & $14.67 \pm 0.88$ \\
\hline $500 \mu \mathrm{g}$ & $15.33 \pm 0.33$ & $15.67 \pm 1.20$ \\
\hline \multicolumn{3}{|c|}{ Standard Antibiotics } \\
\hline $\begin{array}{l}\text { Erythromycin } \\
(15 \mu \mathrm{g})\end{array}$ & - & - \\
\hline $\begin{array}{l}\text { Chlorampheni- } \\
\text { col }(30 \mu \mathrm{g})\end{array}$ & $21.67 \pm 0.88$ & $21.33 \pm 0.67$ \\
\hline $\begin{array}{l}\text { Amoxicillin } \\
(30 \mu \mathrm{g})\end{array}$ & $12.67 \pm 0.33$ & $12 \pm 0.58$ \\
\hline $\begin{array}{l}\text { Ampicillin } \\
(10 \mu g)\end{array}$ & - & - \\
\hline $\begin{array}{l}\text { Penicillin-G } \\
(10 \mu \mathrm{g})\end{array}$ & - & - \\
\hline $\begin{array}{l}\text { Tetracycline } \\
(30 \mu \mathrm{g})\end{array}$ & $14.67 \pm 0.88$ & $15.67 \pm 0.88$ \\
\hline $\begin{array}{l}\text { Ciprofloxacin } \\
(5 \mu \mathrm{g})\end{array}$ & $12.67 \pm 0.33$ & $11.67 \pm 0.33$ \\
\hline $\begin{array}{l}\text { Streptomycin } \\
(100 \mu \mathrm{g})\end{array}$ & $9.67 \pm 0.33$ & $11.33 \pm 0.88$ \\
\hline
\end{tabular}

$\mathrm{SE}=$ standard error, $-=$ No zone; ${ }^{a}$ Diameter Zone of inhibition $(\mathrm{mm})$ including disc diameter $6 \mathrm{~mm}$; ${ }^{b}$ Results of triplicate analysis.

freshwater fish. Chemical ZnO-NPs (105-122 nm), chemical CuONPs and green Ag-NPs show better inhibition against all bacteria, than others. However, the authors did not include any antibiotics in the study. Shaalan et al., (2017) also used commercial $\mathrm{ZnO}-\mathrm{NPs}(\approx 66 \mathrm{~nm})$ and oxytetracycline against six pathogens from infected fish samples. The $\mathrm{ZnO}$-NPs exhibited antibacterial activity against $A$. hydrophila (common bream), $A$. salmonicida subsp. Salmonicida (rainbow trout) and Yersinia ruckeri (rainbow trout), but fail to inhibit growth of E. ictaluri (channel catfish), E. tarda (discus) and Francisella noatunensis subsp. orientalis (Malawi cichlid). In our study, laboratory synthesized green $\mathrm{ZnO}-\mathrm{NP}$ as well as eight standard antibiotics were tested against the pathogenic strain for direct comparison. Interestingly, AVGE$\mathrm{ZnO}-N P s(37.5-63.75 \mathrm{~nm}$ ) were found to be equally effective, even at lower doses, towards multiple antibiotic-resistant, A. veronii and S. maltophilia, in the study. There are differences in the results of antibacterial activity of nanoparticles including $\mathrm{ZnO}$, based on size, dose and species (Swain et al., 2014). This is the first in-vitro study to demonstrate the inhibitory effects of green 

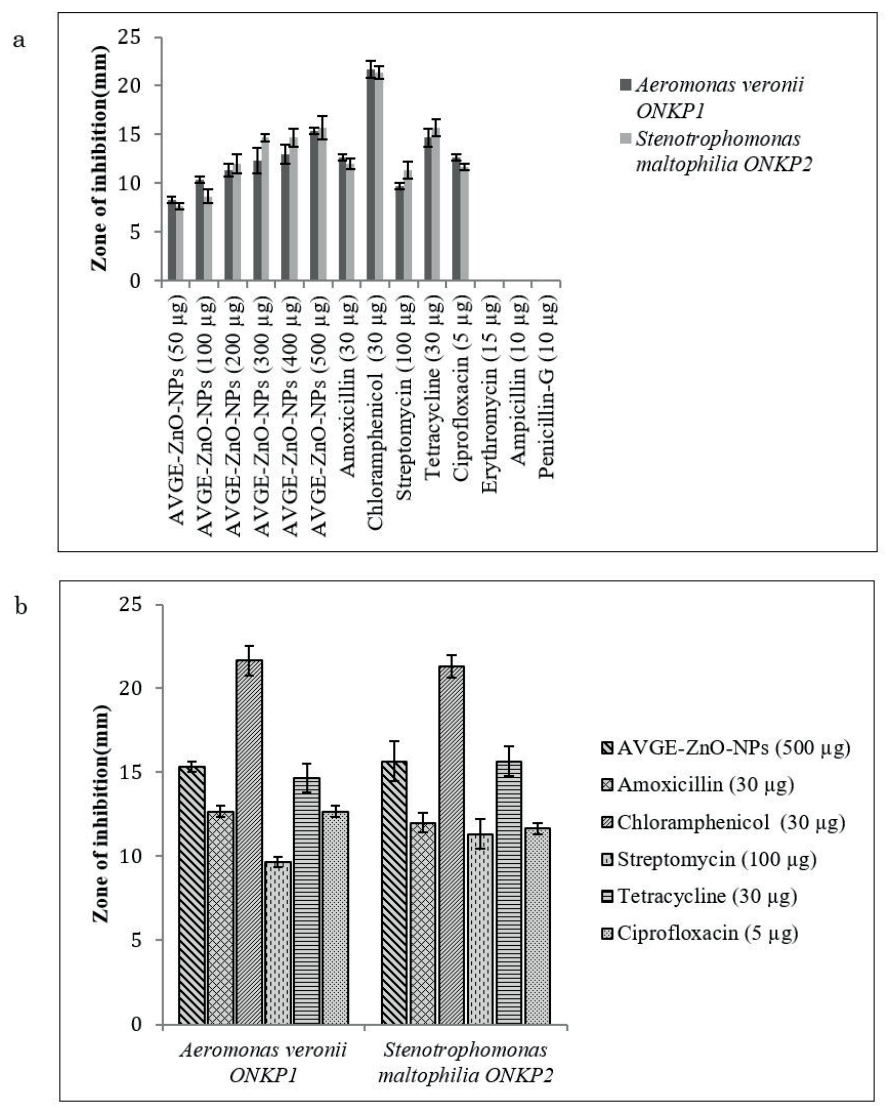

Figure 7. Graphical representation of Zone of inhibition ( $\mathrm{mm}$ ) against bacterial pathogens for antimicrobials; a) Different antimicrobials used in test; b) Comparison between AVGE-ZnO-NPs (highest dose) and the antibiotics to which the bacteria showed susceptibility (error bars represent the mean \pm SE of three replicates; concentration of samples as $\mu \mathrm{g} /$ disc).

or Aloe functionalized $\mathrm{ZnO}-\mathrm{NPs}$ against the multi antibiotic-resistant fish pathogen, A. veronii and S. maltophilia, in addition to their isolation from fresh live marketed, O. niloticus. However, synthesized $\mathrm{ZnO}-\mathrm{NPs}$ may behave differently in live fish and to other pathogenic bacteria. It is a subject of further experimental study which can be carried out in the future.

Nanotechnology is rapidly incorporating into aquaculture by providing new nano-enabled products with novel and unique functions (Luis et al., 2019). But, nanoparticles could be a source of new contamination in the aquatic ecosystem. Studies have shown some toxic effects of $\mathrm{ZnO}$-NPs on aquatic species (Connolly et al., 2016; Kaya et al., 2016; Skjolding et al., 2016; Chupani et al., 2018). The toxicity potential of $\mathrm{ZnO}-\mathrm{NPs}$ is reported to depend on the exposure route, contact time, concentration, environment and target organism (Swain et al., 2016; Khosravi-Katuli et al., 2017; Elshama et al., 2018; Shah \& Mraz, 2020). In freshwater, $\mathrm{ZnO}$-NPs generally tend to dissolve rapidly, increasing the risk of acute toxicity for aquatic organisms (Shaalan et al., 2017).

\section{CONCLUSION}

In summary, the results of our study indicates that the green synthesis of $\mathrm{ZnO}-\mathrm{NPs}$ using Aloe vera gel extract is simple, rapid, convenient and cost-effective. $A$. vera has been also found to be equally effective in capping and stabilization of $\mathrm{ZnO}-\mathrm{NPs}$. In this study, the synthesized biogenic $\mathrm{ZnO}$-NPs showed strong inhibitory activity towards multi-drug resistant fish pathogenic bacteria, A. veronii and S. maltophilia, even at a low dose in the disc diffusion assay. Thus the synthesized biogenic $\mathrm{ZnO}-\mathrm{NPs}$ may be utilized as a potential alternative for disease prevention and treatment in fish. However, detailed in-vivo studies accessing the efficacy as well as associated risks and safety of synthesized biogenic $\mathrm{ZnO}$-NPs are needed for application as nano-antibiotics in aquaculture.

Acknowledgements: We express our deep sense of gratitude to the Principal of Mahadevananda Mahavidyalaya for giving us the permission to use UV-Vis spectrophotometer and other laboratory facilities for synthesis of nanoparticles. We also express our gratitude to Prof. Dr. Kumaresh Ghosh, Head of the Department of Chemistry, University of Kalyani, for allowing us to access the FTIR facility. We would like to thank Mr. Prabuddha Sur, Technician of the FTIR instrument, Department of Chemistry, University of Kalyani, for helping us in analysis. We would like to show our gratitude to Dr. Akash Bhattacharya, Technician of the XRD instrument, DST-PURSE-II, Central Instrumentation Laboratory, University of Kalyani. The authors are thankful to Mr. Ayan Mallick, University of Burdwan, for helping in SEM and EDX analysis. We are also thankful to Mr. Pradip Shit and Mr. Saikat Nandi, University of Kalyani, for their help in FTIR and XRD analysis.

Conflict of interest: The authors declare that they have no conflict of interest.

Ethics committee approval: Ethics committee approval is not required.

Funding: The research work receives grant from University Research Scholar (URS) Fellowship, University of Kalyani, West Bengal.

\section{REFERENCES}

Abraham, T. J., Paul, P., Adikesavalu, H., Patra, A. \& Banerjee, S. (2016). Stenotrophomonas maltophilia as an opportunistic pathogen in cultured African catfish, Clarias gariepinus (Burchell, 1822). Aquaculture, 450, 168-172. [CrossRef]

Ali, K., Dwivedi, S., Azam, A., Saquib, Q., Al-Said, M. S., Alkhedhairy, A. A. \& Musarrat, J. (2016). Aloe vera extract functionalized zinc oxide nanoparticles as nanoantibiotics against multi-drug resistant clinical bacterial isolates. Journal of Colloid and Interface Science, 472(2016), 145-156. [CrossRef]

Agarwal, H., Kumar, S. V. \& Rajeshkumar, S. (2017). A review on green synthesis of zinc oxide nanoparticles-An eco-friendly approach. Resource-Efficient Technologies, 3(4), 406-413. [CrossRef]

Anjugam, M., Vaseeharan, B., Iswarya, A., Gobi, N., Divya, M., Thangaraj, M. P. \& Elumalai, P. (2018). Effect of $\beta-1,3$ glucan binding protein based zinc oxide nanoparticles supplemented diet on immune response and disease resistance in Oreochromis mossambicus against Aeromonas hydrophila. Fish and Shellfish Immunology, 76, 247-259. [CrossRef] 
Austin, B. \& Austin, D. A. (2016) Aeromonadaceae Representatives (Motile Aeromonads). In: Bacterial Fish Pathogens. Springer, Cham. [CrossRef]

Awad, A., Zaglool, A. W., Ahmed, S. A. \& Khalil, S. R. (2019). Transcriptomic profile change, immunological response and disease resistance of Oreochromis niloticus fed with conventional and Nano-Zinc oxide dietary supplements. Fish and Shellfish Immunology, 93, 336-343. [CrossRef]

Azizi, S., Mohamad, R. \& Mahdavi Shahri, M. (2017). Green microwaveassisted combustion synthesis of zinc oxide nanoparticles with Citrullus colocynthis (L.) Schrad: characterization and biomedical applications. Molecules, 22(2), 301. [CrossRef]

Bharti, S. K. \& Singh, S. K. (2009). Metal based drugs: Current use and future potential. Der Pharmacia Lettre, 1(2), 39-51.

Bisht, G. \& Rayamajhi, S. (2016). ZnO nanoparticles: a promising anticancer agent. Nanobiomedicine, 3(Godište 2016), 3-9. [CrossRef]

Budiati, T., Rusul, G., Wan-Abdullah, W. N., Arip, Y. M., Ahmad, R. \& Thong, K. L. (2013). Prevalence, antibiotic resistance and plasmid profiling of Salmonella in catfish (Clarias gariepinus) and tilapia (Tilapia mossambica) obtained from wet markets and ponds in Malaysia. Aquaculture, 372, 127-132. [CrossRef]

Chandran, S., Sunny, J. C., Chandran, S. \& Bellan, C. (2018). Enhanced Antimicrobial activity of Aloe vera blended Zinc Oxide Nanoparticles in PVA matrix. Materials Today: Proceedings, 5(8), 16190-16198. [CrossRef]

Chupani, L., Niksirat, H., Velíšek, J., Stará, A., Hradilová, Š., Kolařík, J., Panáček, A. \& Zusková, E. (2018). Chronic dietary toxicity of zinc oxide nanoparticles in common carp (Cyprinus carpio L.): tissue accumulation and physiological responses. Ecotoxicology and Environmental Safety, 147, 110-116. [CrossRef]

Connolly, M., Fernández, M., Conde, E., Torrent, F., Navas, J. M. \& Fernández-Cruz, M. L. (2016). Tissue distribution of zinc and subtle oxidative stress effects after dietary administration of $\mathrm{ZnO}$ nanoparticles to rainbow trout. Science of The Total Environment, 551, 334-343. [CrossRef]

Das, S., Mitra, S., Khurana, S. P. \& Debnath, N. (2013). Nanomaterials for biomedical applications. Frontiers in life science, 7(3-4), 90-98. [CrossRef]

Deb, S., Kalita, P. K. \& Datta, P. (2013). Optical properties of green synthesized ZnO nanocomposites. Indian Journal of Physics, 87(12), 1177-1182. [CrossRef]

De Villiers, M. M., Aramwit, P. \& Kwon, G. S. (2008). Nanotechnology in drug delivery. Springer: Science \& Business Media. ISBN 9780387776675 [CrossRef]

Dimapilis, E. A. S., Hsu, C. S., Mendoza, R. M. O. \& Lu, M. C. (2018). Zinc oxide nanoparticles for water disinfection. Sustainable Environment Research, 28(2), 47-56. [CrossRef]

Elumalai, K., Velmurugan, S., Ravi, S., Kathiravan, V. \& Raj, G. A. (2015). Bio-approach: Plant mediated synthesis of $\mathrm{ZnO}$ nanoparticles and their catalytic reduction of methylene blue and antimicrobial activity. Advanced Powder Technology, 26(6), 1639-1651. [CrossRef]

Elshama, S. S., Abdallah, M. E. \& Abdel-Karim, R. I. (2018). Zinc oxide nanoparticles: therapeutic benefits and toxicological hazards. The Open Nanomedicine Journal, 5(1), 16-22. [CrossRef]

Faiz, H., Zuberi, A., Nazir, S., Rauf, M. \& Younus, N. (2015). Zinc oxide, zinc sulfate and zinc oxide nanoparticles as source of dietary zinc: comparative effects on growth and hematological indices of juvenile grass carp (Ctenopharyngodon idella). International Journal of Agriculture and Biology, 17(3), 568-574. [CrossRef]

Furushita, M., Okamoto, A., Maeda, T., Ohta, M. \& Shiba, T., 2005. Isolation of multidrug-resistant Stenotrophomonas maltophilia from cultured yellowtail (Seriola quinqueradiata) from a marine fish farm. Applied and environmental microbiology, 71(9), 5598-5600. [CrossRef]
Gopalakrishnan, R., Hawley, H. B., Czachor, J. S., Markert, R. J. \& Bernstein, J. M. (1999). Stenotrophomonas maltophilia infection and colonization in the intensive care units of two community hospitals: a study of 143 patients. Heart and lung, 28(2), 134-141. [CrossRef]

Geng, Y., Wang, K., Chen, D., Huang, X., He, M. \& Yin, Z. (2010). Stenotrophomonas maltophilia, an emerging opportunist pathogen for cultured channel catfish, Ictalurus punctatus, in China. Aquaculture, 308(3-4), 132-135. [CrossRef]

Ghosh, K., Banerjee, S., Moon, U. M., Khan, H. A. \& Dutta, D. (2017). Evaluation of gut associated extracellular enzyme-producing and pathogen inhibitory microbial community as potential probiotics in Nile tilapia, Oreochromis niloticus. International Journal of Aquaculture, 7(23), 143-158. [CrossRef]

Gunalan, S., Sivaraj, R. \& Rajendran, V. (2012). Green synthesized ZnO nanoparticles against bacterial and fungal pathogens. Progress in Natural Science: Materials International, 22(6), 693-700. [CrossRef]

Gupta, M., Tomar, R. S., Kaushik, S., Mishra, R. K. \& Sharma, D. (2018). Effective antimicrobial activity of green $\mathrm{ZnO}$ nano particles of Catharanthus roseus. Frontiers in Microbiology, 9, 2030. [CrossRef]

Hassan, M. A., Noureldin, E. A., Mahmoud, M. A. \& Fita, N. A., 2017. Molecular identification and epizootiology of Aeromonas veronii infection among farmed Oreochromis niloticus in Eastern Province, KSA. The Egyptian Journal of Aquatic Research, 43(2), 161-167. [CrossRef]

Hoai, T. D., Trang, T. T., Van Tuyen, N., Giang, N. T. H. \& Van Van, K. (2019). Aeromonas veronii caused disease and mortality in channel catfish in Vietnam. Aquaculture, 513, 734425. [CrossRef]

Janda, J. M. \& Abbott, S. L. (2010). The genus Aeromonas: taxonomy, pathogenicity, and infection. Clinical microbiology reviews, 23(1), 3573. [CrossRef]

Jin, S. E. \& Jin, H. E. (2019). Synthesis, Characterization, and ThreeDimensional Structure Generation of Zinc Oxide-Based Nanomedicine for Biomedical Applications. Pharmaceutics, 11(11), 575. [CrossRef]

Kaya, H., Aydın, F., Gürkan, M., Yılmaz, S., Ates, M., Demir, V. and Arslan, Z. (2016). A comparative toxicity study between small and large size zinc oxide nanoparticles in tilapia (Oreochromis niloticus): Organ pathologies, osmoregulatory responses and immunological parameters. Chemosphere, 144, 571-582. [CrossRef]

Khosravi-Katuli, K., Prato, E., Lofrano, G., Guida, M., Vale, G. \& Libralato, G. (2017). Effects of nanoparticles in species of aquaculture interest. Environmental Science and Pollution Research, 24(21), 17326-17346. [CrossRef]

Looney, W. J., Narita, M. \& Mühlemann, K. (2009). Stenotrophomonas maltophilia: an emerging opportunist human pathogen. The Lancet infectious diseases, 9(5), 312-323. [CrossRef]

Luis, A. I. S., Campos, E. V. R., de Oliveira, J. L. \& Fraceto, L. F. (2019). Trends in aquaculture sciences: from now to use of nanotechnology for disease control. Reviews in Aquaculture, 11(1), 119-132. [CrossRef]

Mahendiran, D., Subash, G., Selvan, D. A., Rehana, D., Kumar, R. S. \& Rahiman, A. K. (2017). Biosynthesis of zinc oxide nanoparticles using plant extracts of Aloe vera and Hibiscus sabdariffa: Phytochemical, antibacterial, antioxidant and anti-proliferative studies. BioNanoScience, 7(3), 530-545. [CrossRef]

Marathe, N. P., Gaikwad, S. S., Vaishampayan, A. A., Rasane, M. H., Shouche, Y. S. \& Gade, W. N. (2016). Mossambicus tilapia (Oreochromis mossambicus) collected from water bodies impacted by urban waste carries extended-spectrum beta-lactamases and integron-bearing gut bacteria. Journal of biosciences, 41(3), 341-346. [CrossRef]

Martínez-Carmona, M., Gun'ko, Y. \& Vallet-Regí, M. (2018). ZnO nanostructures for drug delivery and theranostic applications. Nanomaterials, 8(4), 268. [CrossRef]

Mirzaei, H. \& Darroudi, M. (2017). Zinc oxide nanoparticles: Biological synthesis and biomedical applications. Ceramics International, 43(1), 907-914. [CrossRef] 
Musa, N., Wei, L. S., Shaharom, F. \& Wee, W. (2008). Surveillance of Bacteria Species in Diseased Freshwater Ornamental Fish from Aquarium Shop. World Applied Sciences Journal, 3(6): 903-905.

Nath, M. R., Ahmed, A. N., Gafur, M. A., Miah, M. Y. \& Bhattacharjee, S. (2018). ZnO nanoparticles preparation from spent zinc-carbon dry cell batteries: studies on structural, morphological and optical properties. Journal of Asian Ceramic Societies, 6(3), 262-270. [CrossRef]

Nawaz, M., Sung, K., Khan, S. A., Khan, A. A. \& Steele, R. (2006). Biochemical and molecular characterization of tetracycline-resistant Aeromonas veronii isolates from catfish. Applied and environmental microbiology, 72(10), 6461-6466. [CrossRef]

Onuegbu, C. U., Aggarwal, A. \& Singh, N. B. (2018). ZnO nanoparticles as feed supplement on growth performance of cultured African catfish fingerlings. Journal of Scientific and Industrial Research, 77, 213-218.

Parthasarathy, G., Saroja, M. \& Venkatachalam, M. (2017). Bio-synthesized nano-formulation of zinc oxide-Aloe vera and to study their characterization and antibacterial activities against multiple pathogens. International Journal of Pharmaceutical Sciences and Research, 8(2), 900-907.

Patel, V. K., Sundriyal, P. \& Bhattacharya, S. (2017). Aloe vera vs. poly (ethylene) glycol-based synthesis and relative catalytic activity investigations of $\mathrm{ZnO}$ nanorods in thermal decomposition of potassium perchlorate. Particulate Science and Technology, 35(3), 361-368. [CrossRef]

Pati, P. \& Mondal, K. (2019). A review on the dietary requirements of trace minerals in freshwater fish. Journal of Environment and Sociobiology, 16(2), 171-206

Qian, Y., Yao, J., Russel, M., Chen, K. \& Wang, X. (2015). Characterization of green synthesized nano-formulation ( $\mathrm{ZnO}-\mathrm{A}$. vera) and their antibacterial activity against pathogens. Environmental Toxicology and Pharmacology, 39(2), 736-746. [CrossRef]

Raje, K., Ojha, S., Mishra, A., Munde, V. K., Rawat, C. \& Chaudhary, S. K. (2018). Impact of supplementation of mineral nano particles on growth performance and health status of animals: a review. Journal of Entomology and Zoology Studies, 6(3), 1690-1694.

Sangeetha, G., Rajeshwari, S. \& Venckatesh, R. (2011). Green synthesis of zinc oxide nanoparticles by Aloe barbadensis miller leaf extract: Structure and optical properties. Materials Research Bulletin, 46(12), 2560-2566. [CrossRef]

Shaalan, M., Saleh, M., El-Mahdy, M. \& El-Matbouli, M. (2016). Recent progress in applications of nanoparticles in fish medicine: a review. Nanomedicine: Nanotechnology, Biology and Medicine, 12(3), 701-710. [CrossRef]

Shaalan, M. I., El-Mahdy, M. M., Theiner, S., El-Matbouli, M. \& Saleh, M. (2017). In-vitro assessment of the antimicrobial activity of silver and zinc oxide nanoparticles against fish pathogens. Acta Veterinaria Scandinavica, 59(1), 49. [CrossRef]

Shah, B. R. \& Mraz, J. (2020). Advances in nanotechnology for sustainable aquaculture and fisheries. Reviews in Aquaculture, 12(2), 925-942. [CrossRef]

Singh, A., Singh, N. B., Afzal, S., Singh, T. \& Hussain, I. (2018). Zinc oxide nanoparticles: a review of their biological synthesis, antimicrobial activity, uptake, translocation and biotransformation in plants. Journal of Materials Science, 53(1), 185-201. [CrossRef]
Skjolding, L. M., Sørensen, S. N., Hartmann, N. B., Hjorth, R., Hansen, S. F., \& Baun, A. (2016) A critical review of aquatic ecotoxicity testing of nanoparticles - the quest for disclosing nanoparticle effects. Angewandte Chemie, 55, 15224-15239. [CrossRef]

Sreedharan, K., Philip, R. \& Singh, I. B. (2011). Isolation and characterization of virulent Aeromonas veronii from ascitic fluid of oscar Astronotus ocellatus showing signs of infectious dropsy. Diseases of aquatic organisms, 94(1), 29-39. [CrossRef]

Sundrarajan, M., Ambika, S. \& Bharathi, K. (2015). Plant-extract mediated synthesis of $\mathrm{ZnO}$ nanoparticles using Pongamia pinnata and their activity against pathogenic bacteria. Advanced Powder Technology, 26(5), 1294-1299. [CrossRef]

Sun, J., Zhang, X., Gao, X., Jiang, Q., Wen, Y. \& Lin, L. (2016). Characterization of virulence properties of Aeromonas veronii isolated from diseased Gibel Carp (Carassius gibelio). International journal of molecular sciences, 17(4), 496. [CrossRef]

Swain, P., Nayak, S. K., Sasmal, A., Behera, T., Barik, S. K., Swain, S. K., Mishra, S. S., Sen, A. K., Das, J. K. \& Jayasankar, P. (2014). Antimicrobial activity of metal based nanoparticles against microbes associated with diseases in aquaculture. World Journal of Microbiology and Biotechnology, 30(9), 2491-2502. [CrossRef]

Swain, P. S., Rao, S. B., Rajendran, D., Dominic, G. \& Selvaraju, S. (2016). Nano zinc, an alternative to conventional zinc as animal feed supplement: A review. Animal Nutrition, 2(3), 134-141. [CrossRef]

Tekedar, H. C., Kumru, S., Blom, J., Perkins, A. D., Griffin, M. J., Abdelhamed, H., Karsi, A. \& Lawrence, M. L. (2019). Comparative genomics of Aeromonas veronii: Identification of a pathotype impacting aquaculture globally. PloS one, 14(8), e0221018. [CrossRef]

Thongkao, K. \& Sudjaroen, Y. (2019). Beta-lactamase and integronassociated antibiotic resistance genes of Klebsiella pneumoniae isolated from Tilapia fishes (Oreochromis niloticus). Journal of Applied Pharmaceutical Science, 9(1), 125-30.

Varghese, E. \& George, M. (2015). Green synthesis of zinc oxide nanoparticles. International Journal of Advance Research in Science and Engineering, 4(1), 307-314.

Vimala, K., Sundarraj, S., Paulpandi, M., Vengatesan, S. \& Kannan, S. (2014). Green synthesized doxorubicin loaded zinc oxide nanoparticles regulates the $\mathrm{Bax}$ and $\mathrm{Bcl}-2$ expression in breast and colon carcinoma. Process biochemistry, 49(1), 160-172. [CrossRef]

Xiong, H. M. (2013). ZnO nanoparticles applied to bio-imaging and drug delivery. Advanced Materials, 25(37), 5329-5335. [CrossRef]

Zhou, Q., Lv, J., Cai, L., Ren, Y., Chen, J., Gao, D., Lu, Z. \& Wang, C. (2017). Preparation and characterization of $\mathrm{ZnO} / \mathrm{AGE}$ MNPs with aloe gel extract and its application on linen fabric. The Journal of The Textile Institute, 108(8), 1371-1378. [CrossRef]

Zhu, P., Weng, Z., Li, X., Liu, X., Wu, S., Yeung, K. W. K., Wang, X., Cui, Z., Yang, X. \& Chu, P. K. (2016). Biomedical applications of functionalized $\mathrm{ZnO}$ nanomaterials: from biosensors to bioimaging. Advanced Materials Interfaces, 3(1), 1500494. [CrossRef]

Wang, J., Wang, A. \& Wang, W. X. (2017). Evaluation of nano-ZnOs as a novel $\mathrm{Zn}$ source for marine fish: importance of digestive physiology. Nanotoxicology, 11(8), 1026-1039. [CrossRef]

Watanabe, T., Kiron, V. \& Satoh, S. (1997). Trace minerals in fish nutrition. Aquaculture, 151(1-4), 185-207. [CrossRef] 